\title{
Removal of Ammonia Nitrogen by Activated Sludge Process Using Simultaneous Nitrification Denitrification Method
}

\author{
Junaidi ${ }^{*}$, Sri Sumiyati, Ronauli Sitinjak \\ Environmental Engineering Department, Faculty of Engineering, Diponegoro University, \\ Tembalang, Semarang, 50275, Indonesia
}

\begin{abstract}
Nitrogen concentrations are often found in ammonia, nitrite, nitrate, and neutral nitrogen waters. This research has investigated the simultaneous removal of biological nitrogen nitrification and denitrification (SND) in a continuous flow system of activated sludge processes. This research was conducted by variations in carbon sources is namely glucose and methanol. Variations of $\mathrm{C} / \mathrm{N}$ ratios of 5, 10, and 20 were also carried out. The main parameters were analyzed every day until the end of the research period. The main parameter analyzed is ammonia-nitrogen. Besides, additional parameters were also analyzed in the form of $\mathrm{COD}$, nitrate-nitrogen, nitrite-nitrogen, $\mathrm{pH}, \mathrm{MLSS}$, SVI, and DO. The results of research indicate artificially excess nitrogen wastewater can be treated using SND and can produce sufficiently good effluent quality if the operations are running optimally. The highest ammonia-nitrogen removal efficiency of $100 \%$ shown by the variation of the carbon methanol source and value of the C / N 20 ratio then followed by the C / N 10 ratio of $78 \%$ and the $\mathrm{C} / \mathrm{N} 5$ ratio of $59 \%$. Overall, the data shown appropriate controls for carbon and nitrogen inputs are needed to achieve an efficient SND. Proper SND technology can save operating time and energy, and may replace two traditional stages: biological nitrification and denitrification processes.
\end{abstract}

\section{Introduction}

Nitrogen compounds are nutrient elements and the main components making up organic substances needed for the growth of microorganisms. However, pollution of water bodies by nutrients in the form of nitrogen compounds is one of the problems that arise due to the development of the industry. Some industrialactivities that cause nitrogen are the food industry, milkindustry, domestic wastewater, and hospitals. The concern is that high nitrogen concentrations in water can cause eutrophication and have a detrimental effect on aquatic life [1]. Biological treatment processes with activated sludge are most commonly used to remove nitrogen due to high efficiency and low cost [2]. Usually, also, the activated sludge process can provide a high removal rate in Chemical Oxygen Demand (COD) and a high removal rate in ammonia through

\footnotetext{
* Corresponding author: junaidiundip@gmail.com
} 
nitrification, but does not provide a significant amount of denitrification [3]. According to Machat (2009) that in its development the process of nitrification and denitrification can be carried out in one process and bothof these stepscan be carried out simultaneously in one reactor which leads to simplification of the equipment needed [1]. Therefore, this process has been labeled "Simultaneous Nitrification Denitrification" or SND.

Simultaneous Nitrification Denitrification (SND) is a process which both microbiological reactions occur at the same time and the same bioreactor volume [4]. The process occurs the outside the floc in aerobic conditions and denitrification inside the anoxic floc. As for this research, optimization of nitrogen removal will be modified by the activated sludge process [5] with operations on carbon source variations and $\mathrm{C} / \mathrm{N}$ ratio at low $\mathrm{DO}$ so that microorganism zones formed on the outside and anaerobic zones on the inside. The nitrificationdenitrification process is carried out in one step in the aerobic process.

Through SND, it is possible to produce low nitrogen effluents, produce energy, alkalinity and can save oxygen demand [6]. To support nitrification, a large DO is needed where oxygen is used as an electron acceptor. Whereas, denitrification requires conditions without knowing DO is low with nitrates and nitrites as electron acceptors [6]. DO and characteristic of dissolved substrate floc influence COD and nitrogen removal. Nitrates produced fromnitrification in the aerobic zone will diffuse in the anoxic zone resulting in denitrification. The diffusion process can be seen in Figure 1.

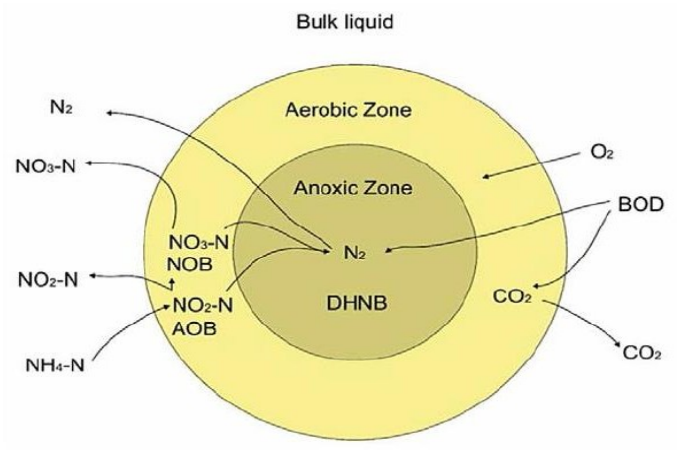

Fig. 1. SND Diagram of Active Sludge Floc

\section{Methodology}

\subsection{Research Location and Time}

The location of research was conducted by the Environmental Laboratory of the Environmental Engineering Department, Diponegoro University. The operating and controlling place of reactor are placed at Green House Environmental Engineering Laboratory, Diponegoro University. Sludge collection is carried out in the gutter of the Penggaron Slaughterhouse, Semarang City. The time was conducted for 6 months from 1 November 2019-30 April2020.

\subsection{Preparation Reactor}

The reactor used consists of four main parts namely inlet storage tank (Marriott tube), aeration tank, clarifier tank, and outlet storage tank. Aeration and deposition tanks are made of glass. Marriott tubes with a capacity of 10Lwith a discharge of 10L/ day as an inlet. Next to the 10L volume aeration tank where biological treatment occurs, $\mathrm{pH} 7 \pm 0.2$ and $\mathrm{DO} \geq 2 \mathrm{mg} / \mathrm{L}$ are the 
control variables. The clarifier tank designed with a volume of $8 \mathrm{~L}$ is used to settle the mud and ends with an outlet. The scheme of activated sludge reactors can be described as follows.

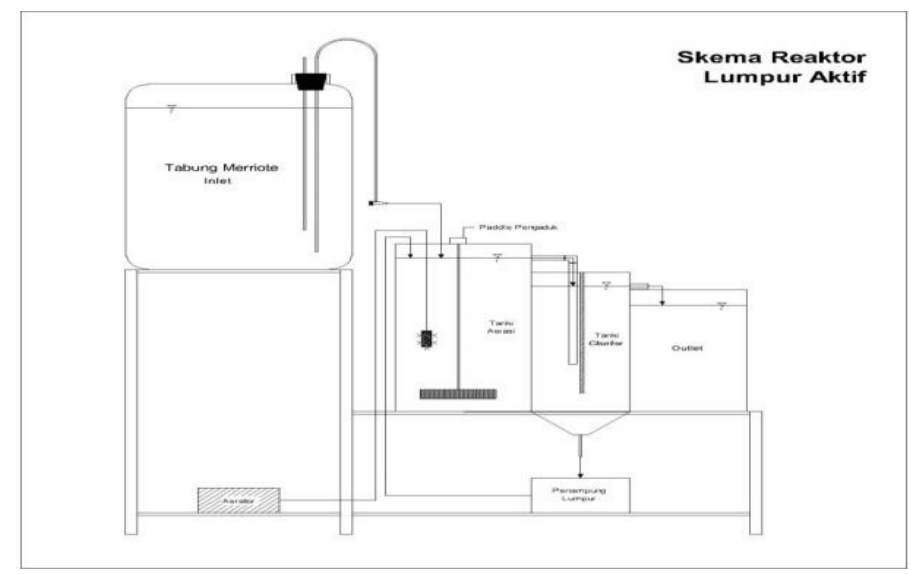

Fig. 2. Activated Sludge Reactor Scheme

\subsection{Preparation of Artificial Waste water}

Data on the composition of waste water under normal conditions is obtained from the calculation of the ratio $\mathrm{C}: \mathrm{N}: \mathrm{P}=100: 5: 1$. However, the ratio used is $\mathrm{C}: \mathrm{N}: \mathrm{P}=100: 30: 1$ because to grow and accustom the presence of nitrifier bacteria in wastewater. The COD content used is $1000 \mathrm{mg} / \mathrm{L}$ and $500 \mathrm{mg} / \mathrm{L}$. Carbon source is taken from glucose dextrose and methanol as much as $12 \mathrm{gr}$ and 6 grams, nitrogen is taken from Ammonium Chloride $(\mathrm{NH} 4 \mathrm{Cl})$ as much as $0.923 \mathrm{gr}$ and source of P from Dipotassium Phosphate (K2HPO4) as much as $0.252 \mathrm{gr}$.

Wastewater of treatment discharge is amount $10 \mathrm{~L} /$ day so that we get a water retention time in aeration tank of 1 day. Constant discharge is obtained by using a marionette tube that uses the principle of air pressure. Other operational parameters of activated sludge are food to microorganism ratio (F/M) 0.3-0.6 $\mathrm{mg}$ COD/ $\mathrm{mg}$ MLSS.day, Dissolved Oxygen(DO) $\leq 2 \mathrm{mg} /$ $\mathrm{L}$, and $\mathrm{pH} 7.0 \pm 0.2$.

\subsection{Preparation of Seeding and Acclimatization}

Seeding is done by a batch reactor system. Microorganism breeding is done without the addition of a starter because it uses microbes that are in gray water obtained in the gutter of Penggaron Slaughterhouse, Semarang City. The reactor is used with a volume of 10L. Artificial waste used contains $\mathrm{COD} \pm 1000 \mathrm{mg}$ / L with a nutritional ratio of C: N: $\mathrm{P}=100: 5: 1$. Seeding was successful when it reached MLSS $\geq 2000 \mathrm{mg} / \mathrm{L}$. Furthermore, the acclimation process is carried out with a continuous reactor system. Acclimatization I aim to adapt bacteria to organic compounds by adding artificial waste from glucose solution. In the acclimation stage II, nitrogen is added to grow and get used to the presence of nitrifier bacteria in wastewater. During the seeding-acclimatization process, samples are taken at each reactor to measure $\mathrm{pH}$, temperature, and COD concentration. The $\mathrm{pH}$ value is kept in the range of $7.0 \pm 0.2$. The seeding-acclimation process is carried out for 29 days.

The seeding process and acclimatization can be stopped when the COD removal is relatively constant with a difference in the efficiency of the COD removal(standard deviation) $\pm 10 \%$. These conditions represent the condition of bacteria that have reached the stationary 
phase and ready to be used for research.

\subsection{Analysis Parameters}

After the reactor has been prepared and the sludge has been acclimatized, the research is ready to be carried out. Wastewater from the Marriott tube flows into the aeration tank with a discharge of $0.12 \mathrm{~mL} / \mathrm{sec}$. Variations in research namely carbon sources are used as independent variables in this research by comparing the use of glucose $\left(\mathrm{C}_{6} \mathrm{H}_{12} \mathrm{O} 6\right)$ and methanol $(\mathrm{CH} 3 \mathrm{OH})$. The $\mathrm{C}$ / $\mathrm{N}$ ratio was used as independent variable in this research by comparing the $\mathrm{C} / \mathrm{N} 5$ ratio (COD $500 \mathrm{mg} / \mathrm{L}, \mathrm{NH} 3-\mathrm{N} 100 \mathrm{mg} / \mathrm{L}$ ), C / N ratio 10 (COD $500 \mathrm{mg} / \mathrm{L}, \mathrm{NH} 3-\mathrm{N} 50 \mathrm{mg} / \mathrm{L}$ ), C / N ratio 20 (COD $500 \mathrm{mg} / \mathrm{L}, \mathrm{NH} 3-\mathrm{N} 25 \mathrm{mg} / \mathrm{L}$ ).

Laboratory testing for each parameter refers to SNI 6989.2-2009 on How to Test CODwith Closed Reflux by Spectrophotometry; SNI 06.6989.30-2005 concerning How to Test Ammonia Levels with Nessler Spectrophotometer; SNI 06.6989.09-2004 concerning Nitrite Test Method (NO2-N) by Spectrophotometer; SNI 6989.74-2009 concerning Nitrite Test Method (NO3-N) by Spectrophotometer; SNI 19-6447-2000 concerning Performance Testing Methods for Active Sludge Processors for MLSS and SVI. The method used in analyzing relations between variables is to make a graph that illustrates the difference from the concentration of the test parameters before processing and after processing, namely the ammonia and CODconcentration data in the reactor with the variation of the $\mathrm{C} / \mathrm{N}$ ratio and carbon sources to get the optimum amount.

\section{Result and Discussion}

\subsection{Seeding Process}

The seeding process in this research serves to multiply the population of microorganisms by adding batch sludge to the reactor. The seeding process requires an environmental condition that supports the optimal growth and development of microorganisms to maintain a $\mathrm{pH}$ of $7.0 \pm$ 0.2 if the $\mathrm{pH}$ tends to be acidic, adding bases $(\mathrm{NaOH})$, whereas if the $\mathrm{pH}$ tends to be alkaline, adding acid ( $\left.\mathrm{H}_{2} \mathrm{SO} 4\right)$.

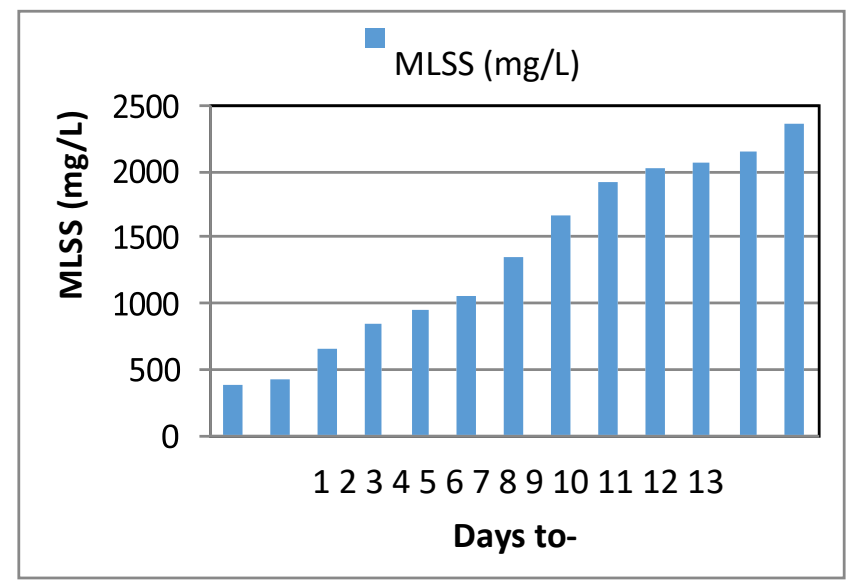

Fig. 3. The Value of MLSS during the Seeding Process 
This indicates that the increase in the value of MLSS as an increase in the number of microorganisms in the reactor. The process of bacterial culture in the research was characterized by MLSS values $\geq 2000 \mathrm{mg}$ / L that was obtained on the 10th day. The seeding process for 13 days has shown the growth of microorganisms in the reactor so that the microorganism acclimation process can be carried out.

\subsection{Acclimatization Process}

The first stage is done without the addition of excess nitrogen aimed at adapting the bacteria to set aside organic compounds. Acclimatization for normal conditions uses nutrients with a ratio of C: N: P = 100: 5: 1 [6] and the COD content in artificial waste or inlet COD is $1000 \mathrm{mg} / \mathrm{L}$ sourced from glucose to carbon, $\mathrm{NH} 4 \mathrm{Cl}$ for nitrogen, and $\mathrm{K}_{2} \mathrm{HPO} 4$ for phosphorus. The making of artificial waste is done by dissolving 12 grams of glucose, $\mathrm{NH} 4 \mathrm{Cl} 0.92 \mathrm{gr}$, and K2HPO4 0.25 gr in 10 Liters of groundwater.

Figure 4 shown COD removal is still fluctuating from day 1 to day 15 . The COD removal is constant from day 15 to day 30, the results of the COD measurements show a significant decrease so that the COD efficiency ranges $82 \%-89 \%$. The success of acclimatization is indicated by the standard deviation value of COD removal efficiency of less than $10 \%$, then the acclimatization is declared successful, the parameters observed in this acclimatization are COD out, while the controlvariables are debit 10L/ day, DO $\geq 2 \mathrm{mg} / \mathrm{L}$ and $\mathrm{MLSS} \geq 2000 \mathrm{mg} / \mathrm{L}$ based on the conventional application of activated sludge in the field according to design criteria [6]. The mean inlet COD concentration at acclimatization I was $911 \mathrm{mg} / \mathrm{L}$.

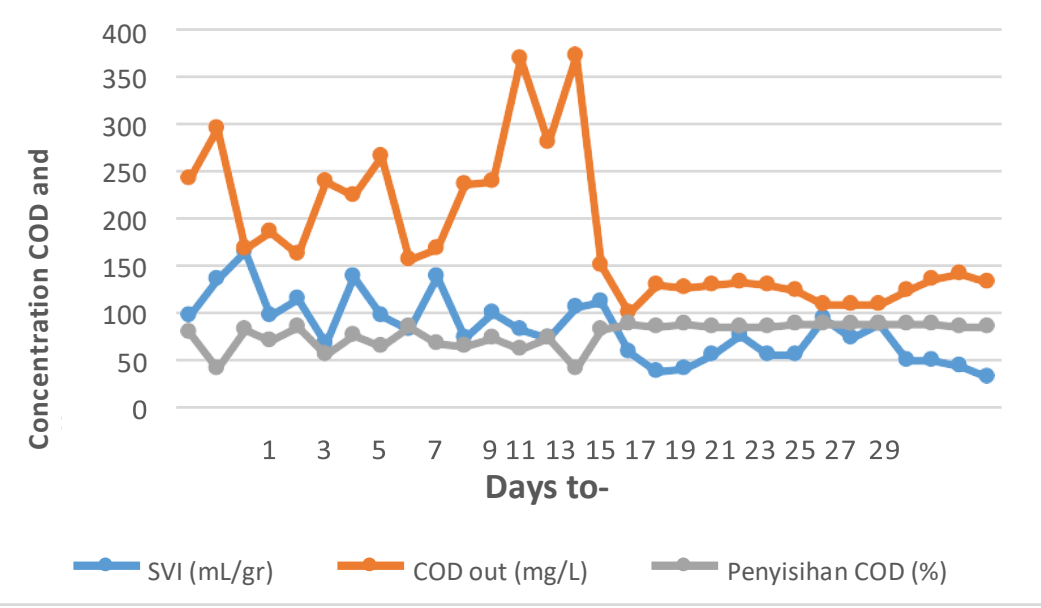

Fig. 4. SVI Graph, COD out and COD Allowance during Acclimatization I

Acclimatization II was carried out with a different treatment from phase I acclimatization by reducing the COD concentration to $500 \mathrm{mg} / \mathrm{L}$. Then the acclimation process is carried out with a ratio of $\mathrm{C}: \mathrm{N}: \mathrm{P}=100: 30$ : 1 by dissolving glucose $6 \mathrm{gr}, \mathrm{NH} 4 \mathrm{Cl} 2.76$ gr and $\mathrm{K} 2 \mathrm{HPO} 40.12$ gr in 10 Liters of groundwater due to growing or accustoming the presence of nitrifier bacteria in wastewater. 


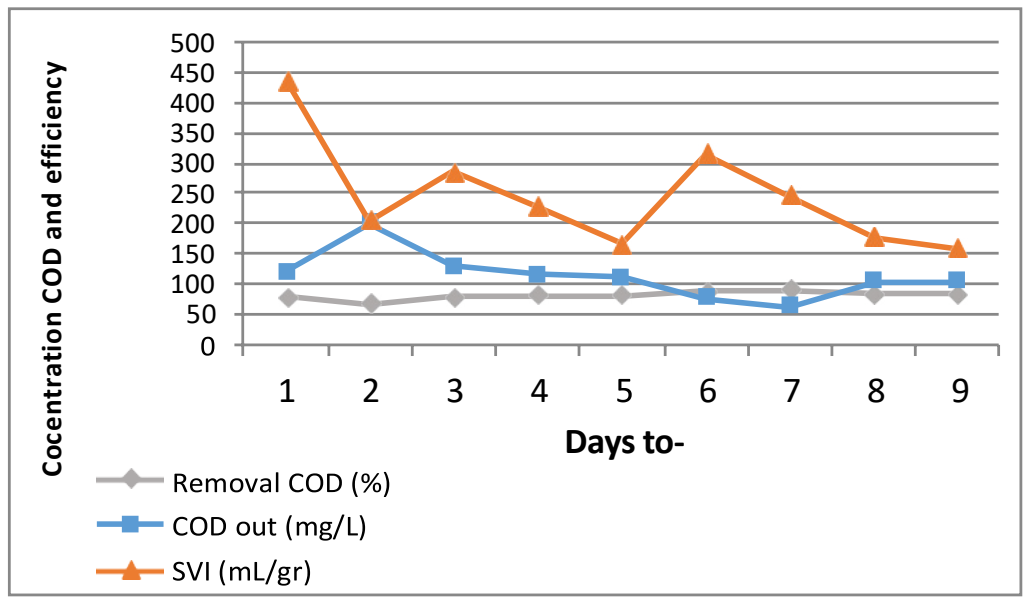

Fig. 5. SVI Graph, COD out and COD Allowance during Acclimatization I I

Figure 5 shown fluctuations in CODremoval from day 1 to day 3 afterthe addition of excess nitrogen and bacterial conditions are still adjusting to artificial glucose wastewater with COD concentrations reduced to an average of $562 \mathrm{mg} / \mathrm{L}$. The constant COD removal occurred on day 4 to day 9, the results of the COD test showed a decrease to obtain COD efficiency in the range of $80 \%-89 \%$. The success of acclimation II is marked by a standard deviation value or $\mathrm{R}^{2}$ of less than $10 \%$, then the acclimatization is declared successful, the parameterobserved in this acclimatization is COD out, while the control variable is a debit of $10 \mathrm{~L} / \mathrm{day}, \mathrm{DO} \geq 2 \mathrm{mg} / \mathrm{L}$ and MLSS $\geq 2000 \mathrm{mg} / \mathrm{L}$ based on the conventional application of activated sludge in the field according to design criteria [6].

\subsection{Results and Discussion of Ammonia-Nitrogen Allowance}

Ammonia-nitrogen removal contained in excess artificial nitrogen wastewater is one of the parameters in this research using the activated sludge system with the Simultaneous Nitrification Denitrification (SND) method. The ammonia-nitrogen analysis is carried out every day on each influent artificial wastewater and effluent results of processing using Simultaneous Nitrification Denitrification (SND).

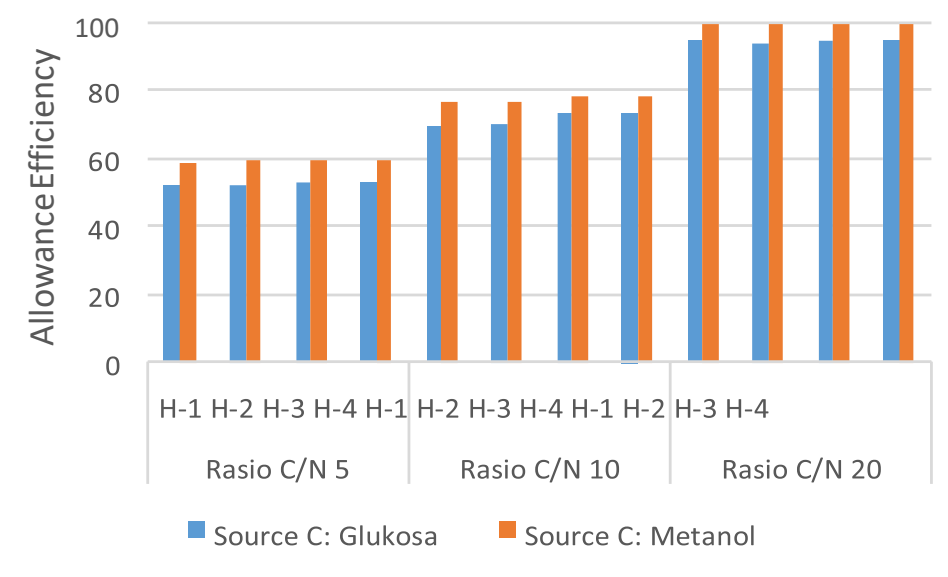

Fig. 6. Ammonia Allowance Efficiency for Each Carbon Source Variation 
Figure 6 shown the efficiency of ammonia-nitrogen removal in this research is ranged from $52 \%-100 \%$. Variations in carbon sources and $\mathrm{C} / \mathrm{N}$ ratio affect ammonia removal. Ammonia removal with variations in the carbon glucose source the most optimal results was obtained at a $\mathrm{C}$ / $\mathrm{N} 20$ ratio of $95 \%$ on day 4 and the mean allowancewas $94 \%$. In the $\mathrm{C} / \mathrm{N}$ ratio 10 , the ammonia removal was $73 \%$ and the average allowance was $72 \%$. Whereas when the $\mathrm{C} / \mathrm{N} 5$ ratio gets an ammonia allowance of $53 \%$ on the 4 th day and the average allowance is at $53 \%$ as well. In the variation of the carbon methanol source, the most optimal ammonia removal at a $\mathrm{C} / \mathrm{N}$ ratio of $100 \%$ was on the 4 th day and the allowance was $100 \%$. Whereas when the C/ N 5 ratio gets an ammonia allowance of $60 \%$ on the 4 th day and the average allowance is at $59 \%$. In the $\mathrm{C} / \mathrm{N}$ Ratio 10 , the ammonia allowance of $79 \%$ and the average allowance at $78 \%$.

Variable carbon source and $\mathrm{C} / \mathrm{N}$ ratio in the research influence on the efficiency of ammonia-nitrogen removal which is increasing every day. It is also influenced by various factors that can support the removal of ammonia, including the concentration of dissolved oxygen, temperature, and $\mathrm{pH}$. The increase in ammonia-nitrogen removal efficiency can also be caused by the degradation process of organic compounds which is quite stable so that the ammonia-nitrogen levels will decrease again. Because in the process of degradation of organic compounds will produce one of the new compounds in the form of ammonia.

Meanwhile, a high $\mathrm{C} / \mathrm{N}$ ratio (relatively low $\mathrm{N}$ content) will cause the degradation process to take place more slowly because nitrogen will be a growth-rate limiting factor. The $\mathrm{C} / \mathrm{N}$ ratio depends on the contaminants you want to degrade, bacteria as well as on the type of nitrogen used. The nitrification process is influenced by several environmental factors including $\mathrm{pH}$, toxicity, metals, and unionized ammonia. The nitrification process is very sensitive to the $\mathrm{pH}$ value, the rate of nitrification willdecrease significantly if the $\mathrm{pH}$ is below 6,8 . At $\mathrm{pH}$ between 5.8 to 6 , the rate of nitrification maybe only $10 \%$ to $20 \%$ of the nitrification rate at $\mathrm{pH} 7$. So the nitrification process will run optimally at $\mathrm{pH}$ between 7,5 to 8 . Nitrifying microorganisms are very sensitive to various organic and inorganic compounds, making it a good indicator of the presence of toxic organic compounds at low concentrations [8].

The carbon source was research by comparing the use of glucose $\left(\mathrm{C}_{6} \mathrm{H} 12 \mathrm{O} 6\right)$ and methanol $(\mathrm{CH} 3 \mathrm{OH})$. The results showed that the optimum removal of ammonia occurred in carbon methanol sources. Carbon sources in the denitrification process can only take place if the availability of organic carbon as an energy source. Ifnitrites and nitrates in this process function as hydrogen (electron) acceptors, then organic carbon functions as a donor or source of energy. According to Gómez, 2000 that is different carbon sources can also influence bacterial nitrate reduction activities on a pilot-scale of sewage treatment under aerobic conditions [9]. Nitrate reduction activity in waste treatment is higher by giving ethanol as a carbon source compared to methanoland sucrose. The addition of ethanol causes a decrease in nitrate compounds by $40 \%$. The addition of methanol caused a decrease in nitrate compounds by $30 \%$ and the addition of sucrose only caused a decrease of $17,5 \%$.

\subsection{Results and Discussion of COD Allowance}

The main treatment of wastewater is to set aside organic compounds which in this research are represented by COD. COD testing is used to measure the oxygen demand of organic matter in wastewater that can be chemically oxidized by using dichromate in acidic solutions. Inorganic substances oxidized with dichromate increase the content of visible organic matter. The following are the results and removal efficiency of COD concentrations which include active sludge processes with variations in carbon sources and $\mathrm{C} / \mathrm{N}$ ratio. COD figures are a measure for water pollution by organic substances which can naturally be oxidized through microbiological processes and result in reduced dissolved oxygen in the water. 


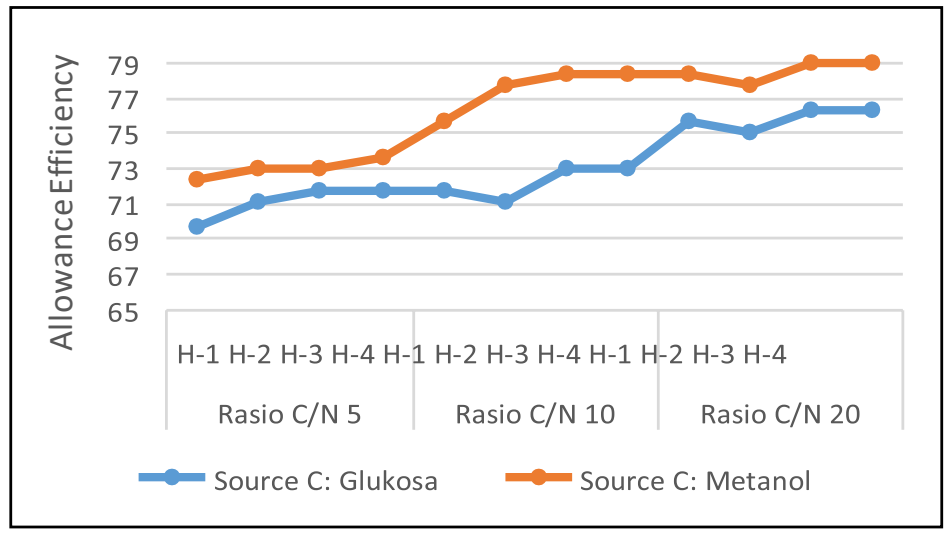

Fig. 7. Ammonia Allowance Efficiency on Variation of C / N Ratio and Carbon Source

Figure 7 shown the efficiency of ammonia-nitrogen removal in this research is ranged from $70 \%-100 \%$. Variations in carbon sources and $\mathrm{C} / \mathrm{N}$ ratio affect COD removal. COD removal with variations in the carbon glucose source the most optimal results was obtained at a C / N 20 ratio of $72 \%$ on day 4 and the mean allowance was $71 \%$. In the $\mathrm{C} / \mathrm{N}$ ratio 10 , the COD allowance is $73 \%$ and the average allowance is $72 \%$. Whereas when the $\mathrm{C} / \mathrm{N} 5$ ratio gets a COD allowance of $76 \%$ on the 4 th day and the mean allowance at $76 \%$ as well. In the variation of the carbon methanol source, the optimalCOD removalwas at a C/ N 20 ratio of $79 \%$ on the 4th day and the allowance was $79 \% . \%$. In the $\mathrm{C} / \mathrm{N}$ ratio 10 , the COD allowance is $78 \%$ and the average allowance is $78 \%$. Whereas when the $\mathrm{C} / \mathrm{N} 5$ ratio gets a COD allowance of $73 \%$ on the 4 th day and the average allowance at $73 \%$ as well. After running it was found that the variation for the most optimumCOD removal was a variation of the carbon methanol source and a C/ N 20 ratio of 79\%. Based on Figure 4.4, it can be seen that an increase in ammonia removal is due to the influence of carbon sources and the $\mathrm{C} / \mathrm{N}$ ratio. At the most optimum carbon, glucose removalallowance occurs at a $\mathrm{C} / \mathrm{N}$ ratio of 20 and followed by $\mathrm{C} / \mathrm{N}$ Ratios 10 and 5 . At the carbon source of glucose, the most optimum removal occurs at a $\mathrm{C} / \mathrm{N}$ ratio of 20 and followed by C/ N Ratios of 10 and 5 .

Microorganisms use nitrogen $(\mathrm{N})$ for the synthesis of proteins and nucleic acids. While most carbon is used, microbes are used for biomass synthesis rather than producing extracellular polysaccharide production (EPS). When the $\mathrm{C} / \mathrm{N}$ ratio is low it will increase the nitrogen element which causes an increase in floc size so that the deposition will take place which is well known with a low SVI value [9]. So according to the statement, because the deposition is going well, the TSS value will be according to which causes the COD removal efficiency to increase [10].

\section{Conclusions}

The conclusions that can be drawn from the research entitled "Optimization of Nitrogen Removal in the Activated Sludge Process with Simultaneous Nitrification Denitrification" include:

1. SND (Simultaneous Nitrification Denitrification) occurred in setting aside ammonianitrogen characterized by the highest percentage of $\mathrm{N}$ denitrification to nitrification when the carbon methanol source and the C / N 20 ratio were 54.09\%. While the highest percentage of $\mathrm{Ndenitrificationto} \mathrm{total} \mathrm{N}$ was at glucoseand $\mathrm{C} / \mathrm{N}$ ratio 5 was $59.21 \%$.

2. The variation of carbon source between glucose and methanol influences on the efficiency of ammonia-nitrogen removal. While the effect of variations in the ratio $\mathrm{C} / \mathrm{N} 5$ (COD $500 \mathrm{mg}$ / L, NH3-N $100 \mathrm{mg} / \mathrm{L}$ ), C / N ratio 10 (COD $500 \mathrm{mg} / \mathrm{L}, \mathrm{NH} 3-\mathrm{N} 50 \mathrm{mg} / \mathrm{L}$ ), $\mathrm{C} / \mathrm{N}$ ratio 20 (COD $500 \mathrm{mg} / \mathrm{L}$, NH3-N $25 \mathrm{mg} / \mathrm{L}$ ) inversely proportional to the ammonia 
removal, the greater the $\mathrm{C} / \mathrm{N}$ ratio the smaller the ammonia removal efficiency.

3. Ammonia-nitrogenremoval is best at $100 \%$ where there is a carbon methanol source and a $\mathrm{C}$ / $\mathrm{N}$ ratio of 20 .

\section{References}

[1] H. Machat, C. Boudokhane, N. Roche, and H. Dhaouadi, "Effects of C/ N Ratio and DO concentration on Carbon and Nitrogen removals in a Hybrid Biological Reactor," Biochem. Eng. J., vol. 151, no. June, p. 107313, (2019), doi: 10.1016/j.bej.2019.107313.

[2] X. Zhang, S. Zheng, X. Xiao, L. Wang, and Y. Yin, "Bioresource Technology Simultaneous nitrification / denitrification and stable sludge / water separation achieved in a conventional activated sludge process with severe filamentous bulking," Bioresour. Technol., vol. 226, pp. 267-271, (2017), doi: 10.1016/j.biortech.2016.12.047.

[3] R. F. Bueno et al., "Simultaneous nitrification and denitrification in the activated sludge systems of continuous flow," vol. 3330, no. August, (2017), doi: 10.1080/09593330.2017.1363820.

[4] E. Gogina and I. Gulshin, "Simultaneous nitrification and denitrification with low dissolved oxygen leveland C/ N ratio," Procedia Eng., vol. 153,pp. 189-194, (2016), doi: 10.1016/j.proeng.2016.08.101.

[5] P. Taylor, B. Durmaz, and F. D. Sanin, "Effect of carbon to nitrogen ratio on the physical and chemical properties of activated sludge Physical and Chemical Properties of Activated Sludge," no. November 2014, pp. 37-41, (2008), doi: 10.1080/09593330309385677.

[6] Metcalf and Eddy, Wasterwater Engeneering - Treatment and Reuse. (2003).

[7] S. R. M. Kutty, M. H. Isa, and L.C. Leong, "Removal of Ammonia-Nitrogen(NH3- N) and Nitrate," vol. 12. pp. 103-107, (2011).

[8] M. A. Gómez, J. González-López, and E. Hontoria-García, "Influence of carbon source on nitrate removal of contaminated groundwater in a denitrifying submerged filter," $J$. Hazard. Mater., vol. 80, no. 1-3, pp. 69-80, (2000), doi: 10.1016/S0304-3894(00)00282$\mathrm{X}$.

[9] F. Ye, Y. Ye, and Y.Li, "Effect of C/N ratio on extracellular polymeric substances (EPS) and physicochemical properties of activated sludge flocs," J. Hazard. Mater., vol. 188, no. 1-3, pp. 37-43, (2011), doi: 10.1016/j.jhazmat.2011.01.043.

[10] Junaidi, "Pengaruh Gradient Kecepatan dan Dissolve Oksigen terhadap Penyisihan COD dan NH3 dengan Simultaneius Nitrification Denitrification Pada Sistem Lumpur Aktif." (2008). 